Original Article

\title{
UTILIZATION OF ETHNO-VETERINARY MEDICINAL PLANTS IN HASSAN DISTRICT OF KARNATAKA, INDIA
}

\section{GOTRUVALLI MANJUNATHA PRASHANTH KUMAR, SHIDDAMALLAYYA NAGAYYA*}

Survey of Medicinal Plants Unit, Regional Ayurveda Research Institute for Metabolic Disorder, (Unit of C. C. R. A. S, Ministry of Ayush), G. C. P. Annexe, Ashoka Pillar, Jayanagar 1st Block, Bangalore 560011

Email: snmathapati@gmail.com

Received: 07 Jan 2017 Revised and Accepted: 14 Feb 2017

\section{ABSTRACT}

Objective: Present work deals with the studies on ethnoveterinary medicinal plants used by local people in Hassan district, Karnataka, India

Methods: The survey was undertaken during 2015-2016 to collect the information on the ethnoveterinary medicinal plants used for treating various diseases in livestock in rural areas.

Results: A total of 36 ethnoveterinary medicinal plants species belonging to 23 families were recorded along with their botanical names, local names, family name, parts used and their ethnomedicinal usage.

Conclusion: Survey was vital importance in finding some miraculous medicines for curing various veterinary diseases.

Keywords: Ethnoveterinary, Medicine, Hassan, Karnataka

(C) 2017 The Authors. Published by Innovare Academic Sciences Pvt Ltd. This is an open access article under the CC BY license (http://creativecommons.org/licenses/by/4.0/) DOI: http://dx.doi.org/10.22159/ijpps.2017v9i4.16975

\section{INTRODUCTION}

Indian agriculture, livestock plays a key role in the farmer's life, they provide farm power, rural transport, manure, fuel, milk, and meat, but also a major role in the rural economy by providing income and employment to the farmers and weaker sections of the society [1]. Ethno veterinary medicine, deal with traditional animal health care which encompasses the knowledge, skills, methods, practices concerning animal health care. The local plants used for the treatment of conventional diseases of livestock and domestic birds are generally called ethno veterinary medicinal plants. Ethnoveterinary medicine is developed by farmers in fields, rather than by scientists in laboratories. The indigenous knowledge of the veterinary health care system acquired by traditional healers is orally transformed from one generation to next generation.

Over centuries, people have developed their own system of keeping animal's healthy and productive using age-old home remedies, surgical and manipulative techniques and religious practice [2]. The use of ethnoveterinary medicine is a cheaper and sustainable alternative to synthetic medicines [3]. Ethnoveterinary medicine usage differs not only from region to region but also among and within communities [4]. Ethnoveterinary medicinal practice and skills have developed through time mainly by trial and error and sometimes through experimentation and innovation [5].

Particularly old practice in large part of the world, in developing countries where animal health service facilities are still very poor or/and, are found scarcely located in urban areas [6]. In rural regions, livestock are regularly affected by different types of diseases due to unavailability of veterinary services; rural poor people exclusively depend on ethnoveterinary practices. In Hassan district, documentation of 194 plant species belonging to 172 genera and 73 families of wild medicinal plants has been recorded (7). The study of ethnobotanical knowledge of ethnoveterinary medicinal plants used by local people of Hassan district not documented yet. This paper is based on data to show the local knowledge of medicine still exists in the Hassan district of Karnataka, which contributes to animal health. The information about local knowledge that was collected remains relevant because farmers' experiences over generations are still valuable, and will possibly be of even greater value in future.

\section{MATERIALS AND METHODS}

\section{Study area}

In Karnataka, Hassan district is located in the south-western part. It lies between $12^{\circ} 13^{\prime}$ and $13^{\circ} 33^{\prime}$ North latitudes and $75^{\circ} 33^{\prime}$ and $76^{\circ}$ $38^{\prime}$ East longitudes with a total area of 6814 sq. Km. It has Tumkur district on its east, Chikkamagalore district towards its north. A South Canara district on the west and on the south is the Mysore district. The Hassan district is divided into 8 taluks viz. Alur, Arakalgud, Arasikere, Belur, Channarayapatna, Hassan, Holenarasipura, and Sakaleshpura with 2,574 inhabited villages (fig. 1). The geography is mixed with Malnad or mountainous region to the west and south-west called Bisle Ghat and the Maidan or plains region in the north, south, and east. There are some areas of degraded forest ranges in the central portion of the district. Hassan district is noted for its rich diversity of plant species, apart from wetlands and floodplains serving the habitat requirement of several inhabitant communities. Most of the families of rural areas are having the practice of maintaining their own small backyard home gardens; almost all families of rural areas have such practices.

\section{Data collection}

The study was conducted among local people including traditional healers and practitioners with knowledge of medicinal plants were selected for the collection of ethnomedicinal information. The information was documented through a survey, interview and field work. The information included details about the botanical and common name of the plant prescribed, part of the plant used, mode of preparation (decoction, paste, powder or juice) and medicinal uses. The information was confirmed through discussions with respondents who practiced the use of the documented plants for veterinary purposes. During the survey, all plants were enlisted, photographed and collected 10-14 inch plant specimen and pressed in the field with collection number. The collected plant specimens from the field along with digital photography and field notes for further processing for herbarium and taxonomical identification. Processed plant specimens to dry and poisoned with $5 \% \mathrm{HgCl} 2$ to mount on herbarium sheets with detailed labelling by following the methods [8-10]. Botanical identification of the species was done with the help of floras [11-13] and also collected plant species were 
cross-verified with the help of preserved authentic herbarium specimens of Regional Research Center Bangalore, India (RRCBI),
Survey of Medicinal Plants Unit, Regional Ayurveda Research Institute for Metabolic Disorder (RARIMD), Jayanagar $1^{\text {st }}$ Block, Bangalore.
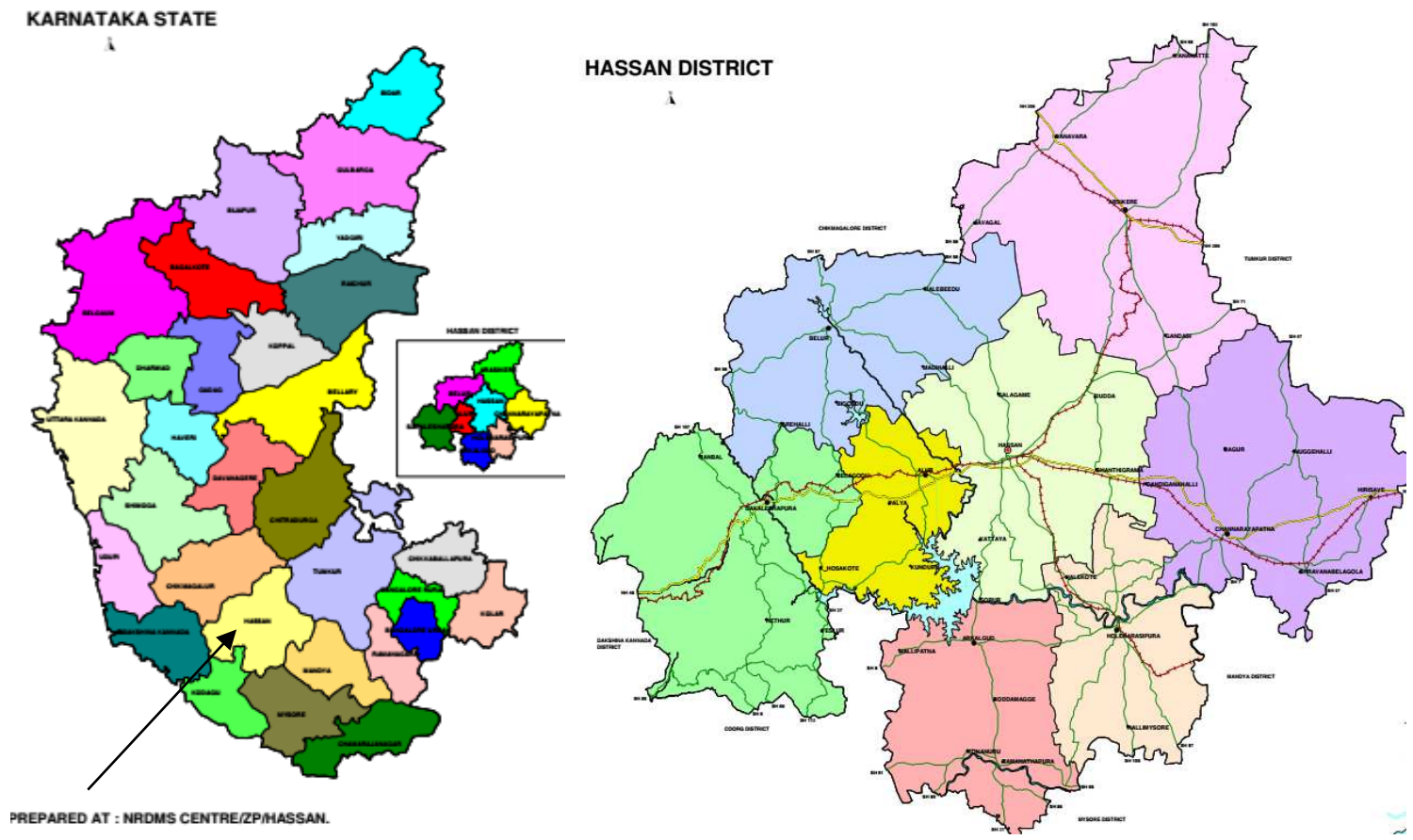

Fig. 1: A detailed study map of the Hassan district

\section{RESULTS AND DISCUSSION}

Ethnobotanical uses of 36 plants belonging to 23 families (table 1 and fig. 3) have been documented in the present study for their interesting therapeutic properties in treating various veterinary ailments such as fever, diarrhoea, cough, foot and mouth disease, to expel intestinal worms, stimulate, prevent premature delivery, retention of placenta, leg damage, eye problem, sore throat, paralysis and joint pain. In the present survey, $36 \%$ of the reported species are the herb. Other highly reported species are the tree $(25 \%)$, shrub (22\%) and the creeper (16\%) (Fig. 2). The common use of herbaceous plants was also reported in other parts of the world [14] and local people used herbs and trees most commonly as medicine due to the availability in surrounding area [15]. The plant parts used by the local people to treat various ailments were mainly leaves, fruits, and seeds. The most frequently utilized medicinal plant's parts were leaves (55\%), followed by root $(10 \%)$, fruit $(7 \%)$, whole plants, seeds, and stem (each 5\%) bark and bulb (each 2\%)(fig. 2). All over the world local communities, utilized for the preparation of herbal medicine using leaves [16-17]. The reason why leaves were used mostly is that they are collected very easily than fruits, flowers and underground parts [18] and in a scientific point of view leaves are active in photosynthesis and production of secondary metabolites [19].

The representation of the families (table 2), among the plants, studied, most of them belonged to the Apocynaceae, Poaceae (4 species each), Euphorbiaceae (3 species), Rubiaceae, Amaranthaceae, Asparagaceae, Asteraceae (2 species each). The rest species belonged to the Anacardiaceae, Liliaceae Mimosaceae, Verbenaceae, Myrtaceae, Menispermaceae, Moraceae, Lamiaceae, Nyctaginaceae, Apiaceae, Oxalidaceae, Araceae, Boraginaceae, Olacaceae and Rhamnaceae family (one species each). The information obtained is comparable favourably with results of similar studies conducted in some other districts of Karnataka [2022]. Of the 36 recorded plant species frequently applied plant species against veterinary ailments included: Justicia adhotoda, Calotropis procera, Asparagus racemosus, Rubia cordifolia, Boerhavia diffusa, Tylophora indica. The same plant material for the same ailment could be prepared in different ways, depending on the preferences of different healers. Regarding Justicia adhotoda, the leaves are used to treat stomach pains, fever, dehydration, diarrhoea, dysentery and indigestion. The leaf paste of this plant has been reported for uses in the treatment of hoof rot in the literature [23]. The therapeutic value of Achyranthes aspera is known for skin diseases [24] and various gastrointestinal and respiratory problems [25]. According to the earlier reports, leaves of Agave americana are used to cure disease like warts, swelling of the throat, constipation, etc. Here, in present study leaf fibers used to tie the fractured bone. Leaves, stems, and twigs of Calotropis procera are applied to cure mouth and eye watering, colic, indigestion, pain and inflammation. Other reports regarding the use of this plant, include latex to increase lactation, crushed leaves for the relief of flatulence, and bark decoction for hoof rot [23]. The leaves and seeds are also reported to be useful for silent oestrus and delayed puberty [26].

The leaf paste of Trichodesma indicum is used to treat stomach disorders and intestinal worms in cattle in the Hassan district, whereas others have reported the use of this paste in the treatment of mastitis and for uterine prolapse [23]. The fruit pickle of Mangifera indica is used for mouth infections. Others have reported that the leaves of the same plant are fed to livestock to treat retained foetal membrane [26]. The seed oil of Ricinus communis is administered to treat constipation. Other studies have documented the use of Ricinus communis for intestinal obstruction, abscesses, hoof problems, wounds, digestive problems, to expel retained placenta and for delayed puberty in cattle [23, 26-27].

The old age residents were more knowledgeable regarding usage of the plants. Similarly, those plants are also used for curing some human ailments and use of plants for both human and animals are a common practice [28]. It was also observed that people living far away from urban area depend on ethnoveterinary medicines. The indigenous documentation knowledge will help the farmers, traditional healers, livestock agents, and village leaders to incorporate and encourage the use of ethnoveterinary medicinal plants in animal health care [29]. 
Habit wise distribution

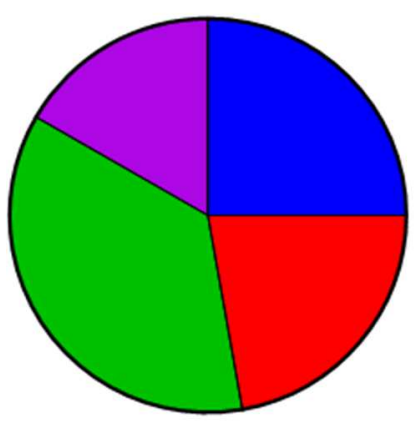

Plant parts used

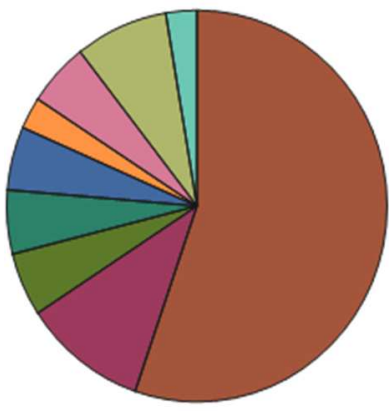

$\mathbf{5 5} \%$ Leaves

$10 \%$ Roots

$\mathbf{5} \%$ Seeds

$\mathbf{5 \%}$ Flowers

$5 \%$ Whole plants

$2 \%$ Bulb

$5 \%$ Stems

$7 \%$ Fruits

2\% Bark

Fig. 2: Showing the habit wise distribution, percentage of plants used for ethnoveterinary medicines

Table 1: Ethnoveterinary medicinal plants used to treat livestock diseases in Hassan district of Karnataka, India

\begin{tabular}{|c|c|c|c|c|c|c|}
\hline $\begin{array}{l}\text { S. } \\
\text { No. }\end{array}$ & Botanical name & Family & Local name & Habit & $\begin{array}{l}\text { Parts } \\
\text { used }\end{array}$ & Ethnoveterinary medicinal uses \\
\hline 1 & Acacia nilotica (L.) Delile & Mimosaceae & Karijali & $\begin{array}{l}\text { Small } \\
\text { thorny tree }\end{array}$ & $\begin{array}{l}\text { Flowers } \\
\text { and Bark }\end{array}$ & $\begin{array}{l}\text { Flowers grinded well and mixed with water, the } \\
\text { solution so obtained is given orally twice daily for } \\
15-20 \mathrm{~d} \text { to cattle to cure jaundice. The extract of bark } \\
\text { is given to cattle orally twice a day for } 10-20 \mathrm{~d} \text { to } \\
\text { cure dysentery }\end{array}$ \\
\hline 2 & Achyranthes aspera $\mathrm{L}$. & Amaranthaceae & Uttarani & Undershrub & Roots & $\begin{array}{l}\text { Fresh root is grounded and the paste applied to cure } \\
\text { bone fracture }\end{array}$ \\
\hline 3 & $\begin{array}{l}\text { Aerva javanica (Burm. f.) } \\
\text { Juss. ex Schult. }\end{array}$ & Amaranthaceae & $\begin{array}{l}\text { Dodda } \\
\text { indigida }\end{array}$ & Herb & Roots & $\begin{array}{l}\text { Roots are boiled in water and decoction is given } \\
\text { twice a day orally for } 7-8 \mathrm{~d} \text { for infection of mouth }\end{array}$ \\
\hline 4 & Agave americana $\mathrm{L}$. & Asparagaceae & Kattale & Bushy herb & Leaves & $\begin{array}{l}\text { Swelling on the fracture part, Leaf fibers used to tie } \\
\text { the fractured bone }\end{array}$ \\
\hline 5 & Allium cepa $\mathrm{L}$. & Liliaceae & Irulli & $\begin{array}{l}\text { Bulbous } \\
\text { herb }\end{array}$ & Bulb & $\begin{array}{l}\text { Bulb is grind and mixed with black salt and used to } \\
\text { drink with water to cure infection of mouth and } \\
\text { hoops }\end{array}$ \\
\hline 6 & $\begin{array}{l}\text { Asparagus racemosus } \\
\text { Willd. }\end{array}$ & Asparagaceae & Shatavari & Creeper & Roots & $\begin{array}{l}\text { Root powder given with milk for one month for the } \\
\text { treatment of arthritis in cattle. The juice, extracted } \\
\text { from leaves and fruits is applied over suffering from } \\
\text { diseases of foot }\end{array}$ \\
\hline 7 & $\begin{array}{l}\text { Bambusa bambos (L.) } \\
\text { Voss }\end{array}$ & Poaceae & Bidiru & Shrub & Leaves & $\begin{array}{l}\text { Leaves are given to cattle twice a day to facilitate } \\
\text { easier removal of placenta after delivery }\end{array}$ \\
\hline 8 & Boerhavia diffusa $\mathrm{L}$. & Nyctaginaceae & Kommegida & Herb & Leaves & $\begin{array}{l}\text { Juice of leaves for thrice a day to cure blood } \\
\text { dysentery and dropsy }\end{array}$ \\
\hline 9 & $\begin{array}{l}\text { Calotropis procera } \\
\text { (Aiton) Dryand. }\end{array}$ & Apocynaceae & Bili yekka & $\begin{array}{l}\text { Errect } \\
\text { shrub }\end{array}$ & Leaves & $\begin{array}{l}\text { Fresh leaves and black salt are fed to animals for } 1-2 \\
\mathrm{~d} \text { to cure mouth and eye watering }\end{array}$ \\
\hline 10 & $\begin{array}{l}\text { Caralluma adscendens } \\
\text { var. fimbriata (Wall.) } \\
\text { Gravely and Mayur. }\end{array}$ & Apocynaceae & Mangana kodu & Herb & Stem & $\begin{array}{l}\text { Plant juice is mixed with coconut oil and heated for } 5 \\
\text { min and applied on the affected parts of mouth }\end{array}$ \\
\hline 11 & Centella asiatica (L.) Urb. & Apiaceae & Ondelaga & Creeper & Leaves & Apply paste of green leaves on forehead during fever \\
\hline 12 & $\begin{array}{l}\text { Cryptolepis dubia (Burm. } \\
\text { f.) M. R. Almeida }\end{array}$ & Apocynaceae & Karibanti & Creeper & Leaves & $\begin{array}{l}\text { Leaves crushed in buttermilk are given twice in the } \\
\text { treatment of snakebite in cattle }\end{array}$ \\
\hline 13 & $\begin{array}{l}\text { Cynodon dactylon (L.) } \\
\text { Pers. }\end{array}$ & Poaceae & Garikehullu & Herb & $\begin{array}{l}\text { Whole } \\
\text { plant }\end{array}$ & $\begin{array}{l}\text { Fresh plant material is ground and } \\
\text { the paste is topically applied for } 2-3 \mathrm{~d} \text { to cure wound } \\
\text { healing }\end{array}$ \\
\hline 14 & $\begin{array}{l}\text { Dendrocalamus strictus } \\
\text { (Roxb.) Nees }\end{array}$ & Poaceae & Hebbidiru & Tree & Leaves & $\begin{array}{l}\text { Frequent coughing, the green leaves of hebbidiru } \\
\text { grind with seeds of bajra and used to eat }\end{array}$ \\
\hline 15 & $\begin{array}{l}\text { Euphorbia heterophylla } \\
\text { L. }\end{array}$ & Euphorbiaceae & Bhedisoppu & Herb & Leaves & $\begin{array}{l}\text { Leaves and seeds are grounded together and mixed } \\
\text { in water and given to livestock in case of food } \\
\text { poisoning. }\end{array}$ \\
\hline 16 & Justicia adhatoda $\mathrm{L}$. & Acanthaceae & $\begin{array}{l}\text { Adumuttada } \\
\text { soppu }\end{array}$ & Shrub & Leaves & $\begin{array}{l}\text { Leaves are mixed with grass or husk and fed to } \\
\text { animal for } 2-3 \mathrm{~d} \text { to cure dysentery }\end{array}$ \\
\hline 17 & Lantana camara $\mathrm{L}$. & Verbenaceae & $\begin{array}{l}\text { Seme seme } \\
\text { huu }\end{array}$ & Shrub & Leaves & $\begin{array}{l}\text { The tender leaves and twigs are grinded and then } \\
\text { decoction are given to cattle for relieving joint pain }\end{array}$ \\
\hline 18 & $\begin{array}{l}\text { Launaea procumbens } \\
\text { (Roxb.) Ramayya and } \\
\text { Rajagopal }\end{array}$ & Asteraceae & Hattarike & Herb & Leaves & $\begin{array}{l}\text { Paste of fresh leaves is topically applied for } 3-4 \mathrm{~d} \text { to } \\
\text { cure skin infection }\end{array}$ \\
\hline 19 & $\begin{array}{l}\text { Mallotus philippensis } \\
\text { (Lam.) Müll. Arg. }\end{array}$ & Euphorbiaceae & $\begin{array}{l}\text { Kumkumada } \\
\text { mara }\end{array}$ & Small tree & Fruits & $\begin{array}{l}\text { Dried fruits are ground and } \\
\text { powder is fed to animals along with wheat flour for } \\
2-3 d \text { to cure intestinal worms }\end{array}$ \\
\hline 20 & Mangifera indica L. & Anacardiaceae & Mavina mara & Large tree & Fruits & $\begin{array}{l}\text { Pickled fruit is fed to animal for } 4-5 \mathrm{~d} \text { to cure mouth } \\
\text { infection }\end{array}$ \\
\hline 21 & Mentha arvensis L. & Lamiaceae & Kadupudina & Herb & Leaves & $\begin{array}{l}\text { Milled fresh leaves and mixed with black salt and used to } \\
\text { eat with water to cure frequent loose motion }\end{array}$ \\
\hline 22 & Mussaenda frondosa $\mathrm{L}$. & Rubiaceae & Beltligida & Shrub & Roots & Root paste is given orally in the treatment of \\
\hline
\end{tabular}




\begin{tabular}{|c|c|c|c|c|c|c|}
\hline 23 & Oxalis corniculata $\mathrm{L}$. & Oxalidaceae & Hulisoppu & Creeper & Leaves & $\begin{array}{l}\text { poisonous bites in cattle } \\
\text { Leaves juice is used to cure white rashes on the } \\
\text { surface of eyeball }\end{array}$ \\
\hline 24 & Pothos scandens L. & Araceae & Agesoppu & Creeper & $\begin{array}{l}\text { Whole } \\
\text { plant }\end{array}$ & $\begin{array}{l}\text { The whole plant is crushed and given to cattle's to } \\
\text { increase lactation }\end{array}$ \\
\hline 25 & Psidium guajava L. & Myrtaceae & Seebe & Small tree & Leaves & $\begin{array}{l}\text { Fresh leaves are boiled in water for half an hour the } \\
\text { extract is then used as drench to cure cuts and } \\
\text { wounds }\end{array}$ \\
\hline 26 & Ricinus communis $\mathrm{L}$. & Euphorbiaceae & Haralu & Shrub & Seeds & $\begin{array}{l}\text { Cup of seed oil is orally administered for up } \\
\text { to a week to constipation }\end{array}$ \\
\hline 27 & Rubia cordifolia L. & Rubiaceae & $\begin{array}{l}\text { Kaikuykana } \\
\text { soppu }\end{array}$ & Herb & Leaves & $\begin{array}{l}\text { Leaf juice applied externally over affected parts of } \\
\text { foot }\end{array}$ \\
\hline 28 & Streblus asper Lour. & Moraceae & Miltimara & Tree & Seeds & $\begin{array}{l}\text { Seed are sundried and grinded and given for } 10-15 \mathrm{~d} \\
\text { to treat mouth disease }\end{array}$ \\
\hline 29 & $\begin{array}{l}\text { Syzygium cumini (L.) } \\
\text { Skeels }\end{array}$ & Myrtaceae & Nerale & Large tree & Leaves & Fresh leaves are fed to animals to cure diarrhoea \\
\hline 30 & Tagetes erecta $\mathrm{L}$. & Asteraceae & Chandu huu & Herb & Leaves & $\begin{array}{l}\text { Milled the fresh leaves and juice is applied externally } \\
\text { to cure shelling off outer layer of horn concomitant } \\
\text { bleeding, }\end{array}$ \\
\hline 31 & $\begin{array}{l}\text { Tinospora sinensis } \\
\text { (Lour.) Merr. }\end{array}$ & Menispermaceae & Amurthaballi & Creeper & Stem & $\begin{array}{l}\text { Stems are grinded and prepared into a thick paste is } \\
\text { applied to skin of livestock to cure skin disease }\end{array}$ \\
\hline 32 & $\begin{array}{l}\text { Trichodesma indicum (L.) } \\
\text { Lehm. }\end{array}$ & Boraginaceae & $\begin{array}{l}\text { Katte } \\
\text { tumbesoppu }\end{array}$ & Herb & Leaves & $\begin{array}{l}\text { Paste of fresh plant is administered orally for a week } \\
\text { for stomach disorder and intestinal worm }\end{array}$ \\
\hline 33 & $\begin{array}{l}\text { Tylophora indica (Burm. } \\
\text { f.) Merr. }\end{array}$ & Apocynaceae & $\begin{array}{l}\text { Adumuttada } \\
\text { balli }\end{array}$ & Undershrub & Leaves & $\begin{array}{l}\text { Leaves are crushed and paste is given twice a day } \\
\text { orally along with ragi balls for } 4 \mathrm{~d} \text { to cure dysentery }\end{array}$ \\
\hline 34 & Ximenia americana $\mathrm{L}$. & Olacaceae & Nagari gida & Tree & Leaves & $\begin{array}{l}\text { The leaf extracts are applied to treat eye infections in } \\
\text { cattle, goats and sheep }\end{array}$ \\
\hline 35 & Zea mays $\mathrm{L}$ & Poaceae & Mekkejola & Herb & Flowers & $\begin{array}{l}\text { Decoction of the female inflorescence } \\
\text { is orally administered for } 4-5 \mathrm{~d} \text { to cure urinary } \\
\text { inflammation }\end{array}$ \\
\hline 36 & Ziziphus jujuba Mill. & Rhamnaceae & Yelechi & Small tree & $\begin{array}{l}\text { Leaves } \\
\text { and } \\
\text { Fruits }\end{array}$ & $\begin{array}{l}\text { The decoction of leaves stops dysentery, the fruit is } \\
\text { laxative }\end{array}$ \\
\hline
\end{tabular}

Table 2: Family-wise distribution of ethnoveterinary medicinal plants in the study area

\begin{tabular}{|c|c|c|}
\hline S. No. & Name of family & Name of plants \\
\hline 1 & Acanthaceae & Justicia adhatoda L. \\
\hline \multirow[t]{2}{*}{2} & Amaranthaceae & Achyranthes aspera $\mathrm{L}$. \\
\hline & & Aerva javanica (Burm. f.) Juss. ex Schult. \\
\hline 3 & Anacardiaceae & Mangifera indica $\mathrm{L}$. \\
\hline 4 & Apiaceae & Centella asiatica (L.) Urb. \\
\hline \multirow[t]{2}{*}{5} & Apocynaceae & Calotropis procera (Aiton) Dryand. \\
\hline & & $\begin{array}{l}\text { Caralluma adscendens var. fimbriata (Wall.) Gravely and Mayur. } \\
\text { Cryptolepis dubia (Burm. f.) M. R. Almeida } \\
\text { Tylophora indica (Burm. f.) Merr. }\end{array}$ \\
\hline 6 & Araceae & Pothos scandens $L$. \\
\hline \multirow[t]{2}{*}{7} & Asparagaceae & Agave americana L. \\
\hline & & Asparagus racemosus Willd. \\
\hline 8 & Asteraceae & $\begin{array}{l}\text { Launaea procumbens (Roxb.) Ramayya and Rajagopal } \\
\text { Tagetes erecta L. }\end{array}$ \\
\hline 9 & Boraginaceae & Trichodesma indicum (L.) Lehm. \\
\hline \multirow[t]{3}{*}{10} & Euphorbiaceae & Euphorbia heterophylla L. \\
\hline & & Mallotus philippensis (Lam.) Müll. Arg \\
\hline & & Ricinus communis L. \\
\hline 11 & Lamiaceae & Mentha arvensis L. \\
\hline 12 & Liliaceae & Allium cepa $\mathrm{L}$. \\
\hline 13 & Menispermaceae & Tinospora sinensis (Lour.) Merr. \\
\hline 14 & Mimosaceae & Acacia nilotica (L.) Delile \\
\hline 15 & Moraceae & Streblus asper Lour. \\
\hline \multirow[t]{2}{*}{16} & Myrtaceae & Psidium guajava $\mathrm{L}$. \\
\hline & & Syzygium cumini (L.) Skeels \\
\hline 17 & Nyctaginaceae & Boerhavia diffusa $\mathrm{L}$. \\
\hline 18 & Olacaceae & Ximenia americana $\mathrm{L}$. \\
\hline 19 & Oxalidaceae & Oxalis corniculata L. \\
\hline \multirow[t]{4}{*}{20} & Poaceae & Bambusa bambos (L.) Voss \\
\hline & & Cynodon dactylon (L.) Pers. \\
\hline & & Dendrocalamus strictus (Roxb.) Nees \\
\hline & & Zea mays L \\
\hline 21 & Rhamnaceae & Ziziphus jujuba Mill \\
\hline 22 & Rubiaceae & Mussaenda frondosa $\mathrm{L}$. \\
\hline & & Rubia cordifolia $\mathrm{L}$. \\
\hline 23 & Verbenaceae & Lantana camara L. \\
\hline
\end{tabular}



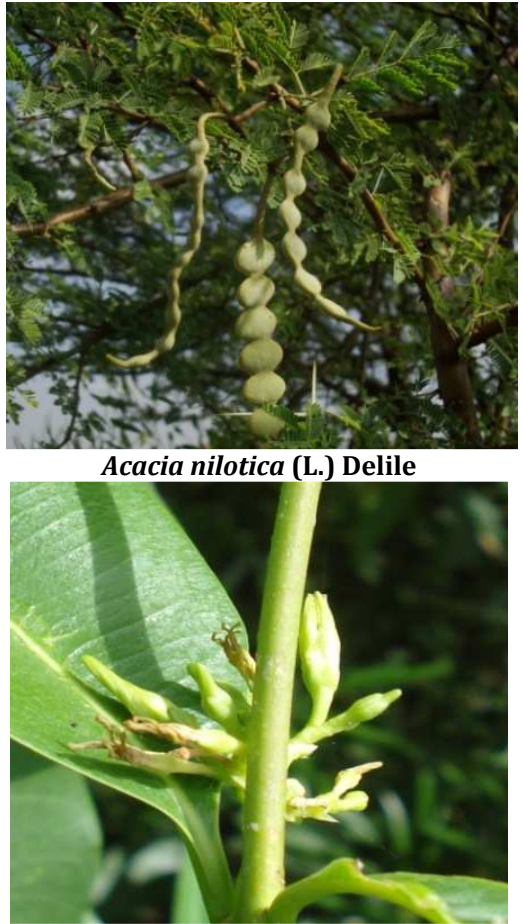

Cryptolepis dubia (Burm. f.) M. R. Almeida

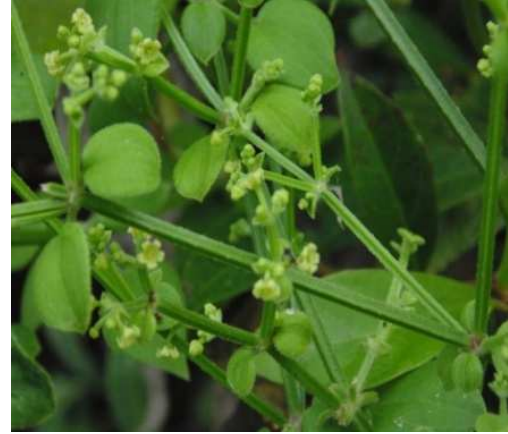

Rubia cordifolia $\mathrm{L}$

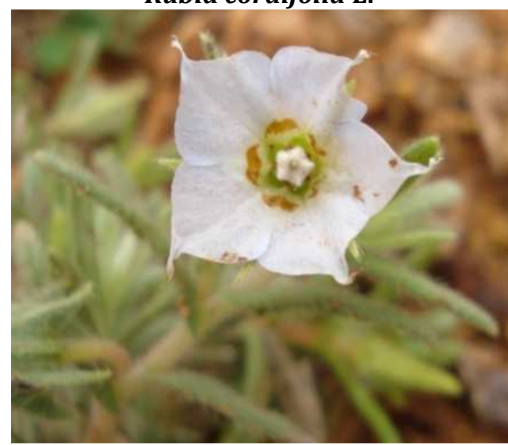

Trichodesma indicum (L.) Lehm.

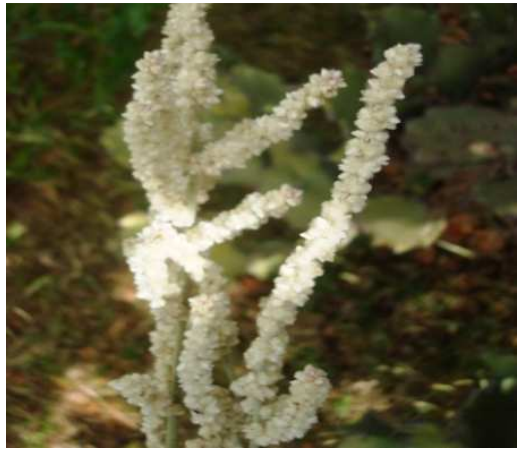

Aerva javanica (Burm. f.) Juss. ex Schult.
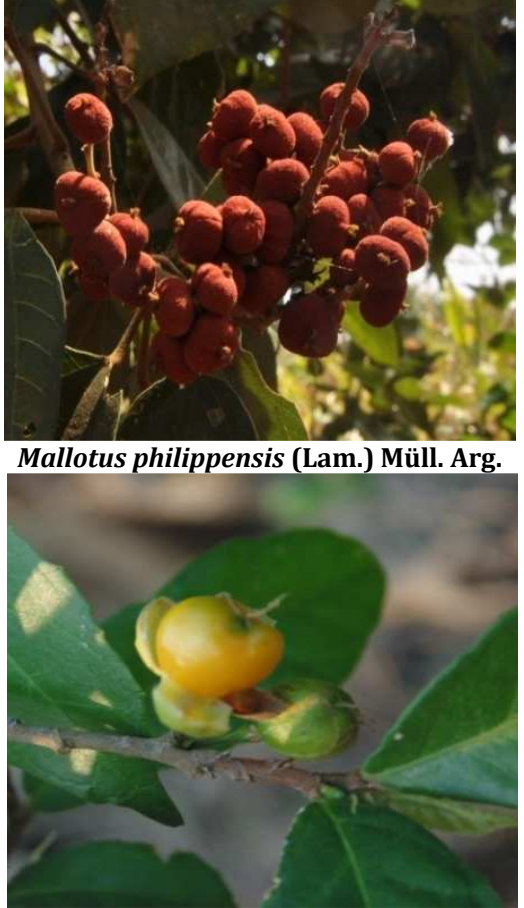

Streblus asper Lour.

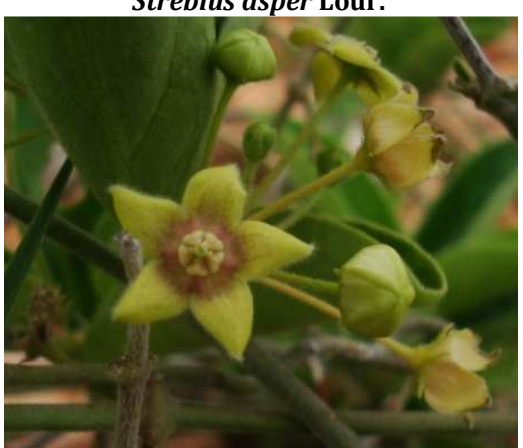

Tylophora indica (Burm. f.) Merr.

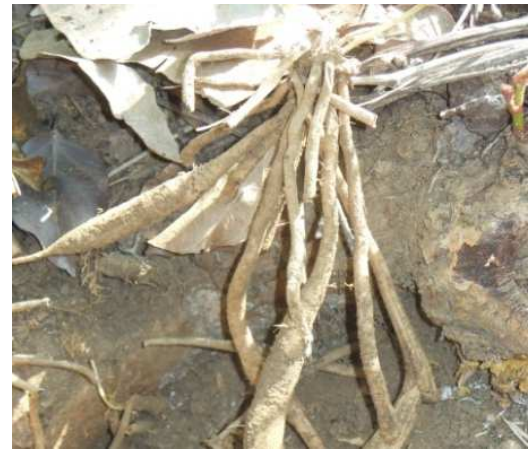

Asparagus racemosus Willd.

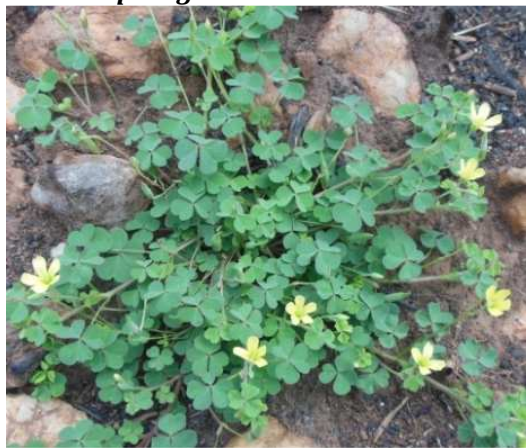

Oxalis corniculata $\mathrm{L}$.

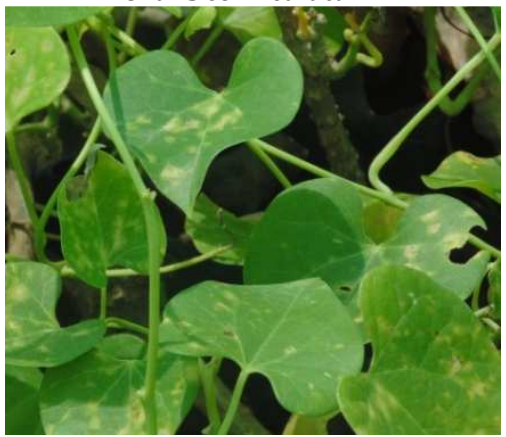

Tinospora sinensis (Lour.) Merr.

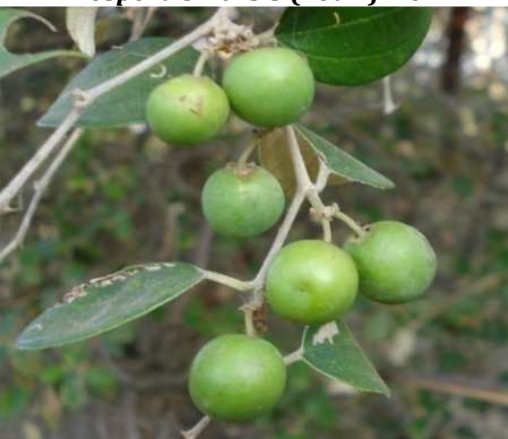

Ziziphus jujuba Mill.

Fig. 3: Showing some of ethno veterinary medicinal plants of Hassan district, Karnataka

\section{CONCLUSION}

The ethnoveterinary medicinal plant species are collected by local people from the surrounding areas, forests and are being used as remedies for various animal ailments. Documentation of ethnoveterinary medicinal plants survey is of vital importance in finding some miraculous medicines for curing various veterinary diseases. Further research focusing on these plants might give information regarding the bioactive compounds to fight diseases in an effective manner.

\section{ACKNOWLEDGMENT}

The authors are grateful to local people of Hassan district for the support and encouragement provided during a survey of ethnoveterinary medicinal plants, Survey of Medicinal Plant Unit, Incharge; Research Officer(S-3), In-charge, RARIMD, Bangalore; Director General, CCRAS, New Delhi, for their encouragement and facilities.

\section{CONFLICT OF INTERESTS}

Declare none

\section{REFERENCES}

1. Verma RK. An ethno botanical study of plants used for the treatment of livestock diseases in Tikamgarh District of Bundelkhand, Central India. Asian Pac J Trop Biomed 2014; 4:S460-7. 
2. Phondani PC, Maikhuri RK, Kala CP. Ethnoveterinary uses of medicinal plants among traditional herbal healers in Alaknanda catchment of Uttarakhand, India. Afr J Tradit Complem 2010;7:195-6.

3. Alam MK. Medical ethnobotany of the Marma tribe of Bangladesh. Econ Bot 1992;46:330-5.

4. Viegi L, Pieroni A, Guarrera PM, Vangelisti R. A review of plants used in folk veterinary medicine in Italy as a basis for a databank. J Ethnopharmacol 2003;89:221-4.

5. McCorkle CM, Mathias E. Animal health biotechnology: building on farmers knowledge. Bunders J, Haverkort B, Heiemstra W. eds. Macmillan Education Ltd. London; 1996.

6. Sinha P, Govil NJ, Singh VK. Diseases and their management, recent progress in medicinal plants, Sci. Tech. Pub LLC, USA; 2002.

7. Prashanth Kumar GM, Shiddamallayya N. Survey of wild medicinal plants of Hassan district, Karnataka. J Med Plants Stud 2016;4:91-102.

8. Meril ED. On the control of destructive insects in the herbarium. J Arnold Arbor 1948;29:103-10.

9. Lawrence GHM. Taxonomy of Vascular Plants. Second Indian Reprint, Oxford and IBH Publishing Co, Calcutta; 1969.

10. Jain SK, Rao RR. A Hand Book of Field and Herbarium Methods. Today and tomorrow's Printers and Publishers, New Delhi; 1977.

11. Saldhana CJ, Nicolson DH. Flora of Hassan District, Karnataka, India Amerind Publishing Co Pvt Ltd, New Delhi; 1978.

12. Saldhana CJ. Flora of Karnataka. Vol. 1. Oxford publishing Co. New Delhi; 1984.

13. Saldhana CJ. Flora of Karnataka. Vol. 2. Oxford publishing Co. New Delhi; 1996.

14. Addo-Fordjour P, Kofi Anning A, Durosimi Belford EJ, Akonno D. Diversity and conservation of medicinal plants in the Bomaa community of the Brong Ahafo region, Ghana. J Med Plants Res 2008;2:226-33.

15. Uniyal SK, Singh KN, Jamwal P, Lal B. Traditional use of medicinal plants among the tribal communities chhota, Western Himalaya. J Ethnobiol Ethnomed 2006;2:14.

16. Morvin Yabesh JE, Prabhu S, Vijayakumar S. An ethnobotanical study of medicinal plants used by traditional healers in the silent valley of Kerala, India. J Ethnopharmacol 2014;154:774-89.

17. Vijayakumar S, Morvin Yabesh JE, Prabhu S, Manikandan R, Muralidharan B. Quantitative ethnomedicinal study of plants used in the Nelliyampathy hills of Kerala, India. J Ethnopharmacol 2015;161:238-54.

18. Giday M, Asfaw Z, Woldu Z. Medicinal plants of the Meinit ethnic group of Ethiopia: an ethnobotanical study. J Ethnopharmacol 2009;124:513-21.

19. Ghorbani A. Studies on pharmaceutical ethnobotany in the region of Turkmen Sahra North of Iran (Part 1): general results. J Ethnopharmacol 2005;102:58-68.

20. Harsha VH, Shripathi V, Hegde GR. Ethnoveterinary practices in Uttar Kannada district of Karnataka. Indian J Tradit Know 2005;4:253-8.

21. Rajkumar N, Shivanna MB. Traditional veterinary healthcare practices in Shimoga district of Karnataka, India. Indian J Tradit Know 2012;11:283-7.

22. Naik RM, Venugopalan V, Kumaravelayutham P, Krishnamurthy YL. Ethnoveterinary uses of medicinal plants among the Lambani community in Chitradurga district, Karnataka, India. Asian Pac J Trop Biomed 2012;S470-6.

23. Ali ZA. Folk veterinary medicine in Moradabad district Uttar Pradesh, India. Fitoterapia 1999;70:340-7.

24. Goyal BR, Goyal RK, Metha AA. Phyto-pharmacology of Achyranthes aspera: a review. Plant Rev 2007;1:143-50.

25. Bhandari MM. Flora of the Indian desert, MPS Reports, Jodhpur, India; 1990.

26. Dilshad SMR, Rehman N, Iqbal Z, Muhammad G, Iqbal A, Ahmed $\mathrm{N}$. An inventory of the ethnoveterinary practices for reproductive disorders in cattle and buffaloes, Sargodha district of Pakistan. J Ethnopharmacol 2008;117:393-402.

27. Lans C, Turner N, Khan T, Brauer G, Lourenco G, Georges K. Ethnoveterinary medicines used for horses in Trinidad and in British Columbia, Canada. J Ethnobiol Ethnomed 2006;2:31.

28. Tabuti JRS, Dhillion SS, Lye KA. Ethnoveterinary medicines for cattle (Bosindicus) in Bulamogi County, Uganda: plant species and mode of use. J Ethnopharmacol 2003;88:279-86.

29. Kannan M, Senthil Kumar T, Rao MV. Ethnobotanical note on the veterinary health-care management by Malayali tribes of Kalrayan hills. Asian J Pharm Clin Res 2016;9(Suppl 1):66-82.

\section{How to cite this article}

- Gotruvalli Manjunatha Prashanth Kumar, Shiddamallayya Nagayya. Utilization of ethnoveterinary medicinal plants in hassan district of Karnataka, India. Int J Pharm Pharm Sci 2017;9(4):107-112. 